\title{
Scientific Review of Hazrat Hassan Basri's Teaching (An Analytical Study)
}

\author{
*, Dr. Hafiz Muhammad Ibrar Ullah Assistant Professor of Islamiyat (Corresponding Author) \\ ** Dr. Hashmat Begum, Assistant Professor of Islamiyat \\ *** Prof. Dr. Hafiz Muhammad Inam Ullah, Professor of Education
}

\begin{abstract}
Hazrat Hassan Basri (may Allah have mercy on him) had the privilege of being born in a time which was a glorious time. He was brought up in the pure society of Madinah. His family consisted of his father, mother, and brother. He listened to the sermons of HazratUsman and had the good fortune to see many of the Companions. And stayed with them as a student. He was one of the most beautiful people in Basra. Let them take their children to seek knowledge. Hazrat Hassan Basri(may Allah have mercy on him) used to urge his disciples to ask questions about the issues which they do not know because those who give up the demand for knowledge due to revival wear the garment of ignorance. Imam Hassan Basri (may Allah have mercy on him) is a grammar expert. He used to say, "Learn knowledge to know religions, and learn medicine for eloquence, and learn grammar for language. Among your teachers is Abu Barza." Aslami, Ahmar, Ahnaf bin Qais, Osama bin Zayd, Jundab bin Abdullah Famous students include Rabi 'ibnSabih, AyasibnMu'awiyah, and Sulayman.
\end{abstract}

Keywords: Renowned Tabi, Education Jurisprudence, Sermons Introduction

Hasan Basri (may Allah have mercy on him) was born in Madinah in 21 A.H, 642 A.D. all through the caliphate of Hazrat Umar Farooq Razi Allahu anhu. Equally, his parent Khayyra as well as Yasar were slaves. Yasar was caught as a prisoner by the Muslims when Muslims conquered man, an area present in Iraq. His father was the slave of Zaid bin Thabit. His father embraced Islam and lived in Madeenah, where he married a bondwoman called Khayyirah who was the maid-slave of Umm Salamh the wife of the Prophet (SAW). The Mother of the Muslim, Umm Salamah freed Khayyirah after she gave birth to her son Hassan. Hassan (may Allah have mercy on him) spent his early years with his familyinWaadiAl-Qura near Madeenah. Hassan Basri has died in110 A.H in Basra. (Akhtar, 2004). He is the revered tabi and the scholar of the people of Basrah, Abu Saeed Al-Hasan Ibn Abi Al-Hasan Ibn Yasar Al-Basri. His quotes and sayings are world-famous, which are nothing but statements of facts and truths (Iftekhar Ahmed, 2019) some hagiographic sources even indicate that Hasan met the Prophet Muhammad (SAW) as an infant. The tradition relates that Muhammad, who "visited Umm Salama's house while the baby was there," "prayed for little Hasan and again bestowed blessings (JhonRenard 2008).

Education of Hassan Basri

Hassan Basri's (may Allah have mercy on him) mother was the maid of Hazrat Umm Salma. She told Hassan Basri's mother, "Take this child to Hazrat Umar for prayers. Hazrat Umar prayed: "O Allah, grant him an understanding of religion and make him beloved of the people and give him superiority over many of His creatures." It is estimated that Hajjaj ibn Yusuf summoned you several times to punish him severely, but when Hasan Basri was present in the court, the pilgrims would stand up and stop and say: You are dearest to me among the people. (AlMadani, 2000)Hassan Basri (may Allah have mercy on him) memorize the Glorious Quran at the age of fourteen years. He also learned reading, writing, and some mathematics. He heard many sayings of the Companions of the Prophet and he used to listen to the leader of the Muslims, 'Usman bin 'Affaan whenever he delivered the Friday sermon. Hassan was fourteen years old at that time. He also narrates hades from the great sahaba, just Hazrat Ali ibn Abi Talib, Hazrat, Abu Musa Ashari, Hazrat Abdullah ibn Umar, Hazrat Abdullah ibn Abbas, Hazrat Anas bin Malik, Hazrat Jabir bin Abdullah (R A). But mostly he inspired from Hazrat Ali ibn Abi Talib (R.A) due to their captivating conspicuous, cleverness cognition full

* The University of Azad Jammu \& Kashmir Muzaffarabad Email: hafizibrar87@gmail.com

** Shaheed Benazir Bhutto Women University Peshawar Email: hashmat.begum@sbbwu.edu.pk

*** IER, University of Peshawar Email: hafizinam@uop.edu.pk 
and rhetoric sententious. (Akhtar, 2004) He was one of the most renowned tabi (the generation after the death of the Prophet) and prominent figures of his time because of his huge learning. He was a jurist and a scholar. He was a pious and devout person (Iftikhar Ahmed, 2019). At the age of fifteen years old, Hasan migrated to Basrah Iraq in 36 A.H.656 A.C. Where he start learning of hadith, jurisprudence, and the Arabic language at the hands of Hazrat Abdullah bin Abbas and other companions of the Prophet who were living in Basrah at that time, Hazrat Abu Musa Ashari, HazratAhnaf bin Qais, HazratAnas bin Malik, Hazrat Imran bin Haseen, Hazrat Abdur Rahman bin Sumora, Hazrat Abdullah bin Muzni, Hazrat Sumra bin Jundob, Hazrat Abu baza Aslami, Hazrat Abu Barda Ansari, Hazrat Ayaz bin Hamad tammimy, Hazrat Ayaz bin Ghanamashari and a lot of other companions of Hazrat Muhammad (SAW). His tutor for the recitation of the Glorious Quran was Ali HattaanIbn 'AbdullaahAr-Riqashi and Abu Alia Raffi bin Mehran. While his tutor for the methodology of delivering sermons, religious speeches, and recounting religious tales, was IbnSurayyi At-Tameemi, the poet. (Akhtar, 2004)

\section{Teaching Methods of Hasan Basri}

Hazrat Hassan Basri (may Allah have mercy on him) used to say that forty years have passed over me in such a state that the book was lying on my chest while I was asleep. (Idrees Raheemi, 2004)According to Rabi Bin Anas, he was an intellectual and knowledgeable person. He was teaching at a time to different classes. Mostly he used the station method of teaching while delivering a lecture in the classes. He was making different groups and then assign the topic to each group for group discussion. After that, he was attending each group and was giving instructions to them on their topic. ( Al Madani, 2000) He was using the discussion method with the stations' method as well. Hassan Basri (may Allah have mercy on him) avoid irrelevant thing and focus on a particular subject. Hassan Basri was taking a class in the Masjid of al Basra in which he thought the glorious Quran, Prophetic Hadith, jurisprudence, the Arabic language, and rhetoric. About the asceticism Hassan Basri also take a class in his house. Hasan was one of the most knowledgeable people in jurisprudence and the lawful and unlawful acts. . (Shah, 2017) He accepts the responsibility of guiding and advising people to save his society from the deflection that was beginning to conquer. Hassan Basri (may Allah have mercy on him) found a lot of period of the sahaba and he was the student of companion so he takes up the doctrine of the companions. He was inspired by their methodology and he led their methodology. While Hassan Basri adopted that methodology for sermon delivery. He always focuses on the life after death and he wants to recover the attention of the people toward Islam and guide them in the light of the Holy Quran and hadith (Nadvi, 2006)

\section{Dictation Method}

According to their students, Hassan Basri (may Allah have mercy on him) was very keen on writing .he wrote many books. He also wrote some books through their students. When Hassan speaks their students dictate him. (Shah, 2017) Hassan Basri (RM) also used Question answer method of teaching. He emphasizes on their students to ask questions from their teacher and don't feel shame in asking questions from their teacher. Once he said I have found knowledge between shameless and tier. He also said that anyone student who feels shame in getting of education his knowledge become weak. (Shah, 2017),

\section{Educational thought of Hassan al Basri}

Hassan Basri (may Allah have mercy on him) said that 'without Knowledge there is no manner, and the person who has no patience has no religion, and the person who does not know their creature he has no closeness to Allah. (Al-'Asqalani I. I., 2004) Imam Hassan Basri (may Allah have mercy on him) then says that if there was no knowledge, people would be like cattle. (Al-Hanbalee) $(1401 \mathrm{H})$ Hassan said that it is beloved me that if a person give precious thing for the cause of ALLAH but the other person learn a single topic and teach it to another Muslim it is more beloved me. It is reported that Hassan said an intelligent person think before speaking if the word in the fever him then he speaks otherwise he stops, while a stooped person any thought that comes on their tongue he speaks, (Ahmad, 2013) Hassan Basri said that: Knowledge without acquiring is not seen in the life of a person, while there is a small portion of acquired Knowledge and put it into their practice it would be better for him from the world and it contains. (Mourad, Suleiman, 2003) Hassan Basri (may Allah have mercy on him) says about the early stage of learning and emphasis that the early stage learning is forever. Early-stage learning is just like engraving on stone. (Ibn-Al jaws, 2012) Hassan Basri (may Allah have mercy on him) said about the superiority of sahaba, that sahaba was most pious hearts of 
this ummah and they have abandoned knowledge and self-controlled and Allah choose them for the brotherhood of Hazrat Muhammad (SAW), (Ahmad, 2013)

\section{Jurisprudential opinion of Hassan Basri}

According to Abu Salma, the jurisprudential opinion and religious decree of Hassan Basri (may Allah have mercy on him) was more than any other of his period. There is no chapter of jurisdiction where there is no critical and jurisprudential opinion of Hassan Basri (may Allah have mercy on him) and he says that I have learned more than eight thousand questions from Hassan Basri. Muhammad bin Ahmad bin Yahiya has combined the jurisprudence of Hassan (may Allah have mercy on him) into seven volumes. (Shah, 2017)Hassan Basri (may Allah have mercy on him) was a great writer and had a good memory. He copied the book of their teacher of Hazrat Sumora bin Jandob (RH) for himself. Hassan Basri (may Allah have mercy on him) compile a lot of Book but he burnt most of them before their death except one which was in the passion of his son .which is taken by Muslim bin Husain as borrow from him. Following are the famous books of Hassan Basri (may Allah have mercy on him). (Ibn-Al jawzi, 2012)A famous interpreter of Quran Yahiya bin Slam narrate and cite the Tafseer of Hassan Basri (may Allah have mercy on him) in their Tafseer, beside Yahiya bin slam most of the interpreter such as Abdur Razzaq, Abad bin Hameed, Ibnul Munzirtabri and ibn Hatam also narrate him in their books. He also write some books such as Resala fi raddil Qadria, Resala fil adly WA towheed, Resala fi Fazile Makka. Kitabul nazool, Kitabul Adad, and Kitabul Ikhlas. Hassan Basri also wrote a lot of letters to the leader of his time. . (Shah, 2017) Hassan Basri (may Allah have mercy on him) was the famous jurisprudence of his time.so Hazrat Qatada said about Hassan whenever I sat with anyone jurist, I found Hassan is the best of all. (Shah, 2017) Hazrat Bakar bin Abdulah Mazni said if the people want to see the great jurist, they should see Hassan Basri (al-Nimri 2010). Imam Ghazali mentioned in his book "Ahyaul-Uloom" that his ideas were too much similar to the messengers of Allah. He was explaining things as prophets of Allah were explaining to Companions. His lifestyle was totally according to the Companion of Prophet. The same things have also been discussed by one of the Non-Muslim philosophers Tabit bin Quran. Tabit bin Qura mentioning further that different philosophers were present in Mecca but when people have seen Hasan Basri (may Allah have mercy on him) and his knowledge they were hanged. Because they haven't seen such a knowledgeable person in his/her lives. (Nadvi, 2006)It is narrated that one day a person stood and asked "Why Hassan is better than us" So a respectable person replied we have need his Knowledge while Hassan does not need Allah. Therefore he is respectable and honorable (Akhtar, 2004).

\section{Skills/Capabilities of Hassan Basri}

Hassan Basri has multi-dimensional teaching skills.

Motivational skills

Keen observer

Rhetoric, Concise and Eloquent

Hassan Basri has a great opportunity that find the age of the Sahaba. Hassan Basri has brilliant intelligence which is essential for the revival and renovation of Islam effective in his time. He was better than his contemporary in the knowledge of the Quran. He is a keen observer and wants the contemporary events of the Muslim will be according to the Islamic society he was also a good orator of his time (al-Ajurri, I. A.-H.) (360H). Hazrat Imam Razi (RA) says that Hazrat Hassan Basri (may Allah have mercy on him) has been favored by Allah over his followers in five ways.

He never used stinginess in talking about knowledge and action. You wouldn't order this thing unless you acted on it. Unless you stop yourself from doing something, don't forbid others. Because of his knowledge, he used to treat people with contempt. Their appearance and inwardness were equal (Saifullah, 2003).

\section{STUDENTS OF HASSAN BASRI}

There are many students of Hassan Basri (may Allah have mercy on him) but there are some who became famous at that time are following.

I. Hazrat Rabbi bin Sabih Abubakar;

II. Hazrat Ayas bin Maawia

III. Hazrat Abu Umar bin alaBasri

IV. Hazrat Abdullah bin Auon

V. Hazrat Suliman Bin Tar khan Qaisy

VI. Hazrat Mansoor bin Muammar 
VII. Hazrat younas bin ubaidabdi

VIII. Hazrat Hasham bin Hassan AzdiQardasy

(Shah, Imam Hassan Basri Ahwal Wa Aasar, 2017)

\section{CONCLUSION}

Hazrat Hassan Basri (may Allah have mercy on him) is a glorious follower for whose knowledge and insight Hazrat Umar Farooq (R.A) prayed. In the same way, the ability to learn and teach which was given to Hazrat Hassan Basri (may Allah have mercy on him). Hazrat Hassan was considered to be the Imam of the Basri Dictionary. He had an important grasp on the rules and regulations of the dictionary. He was well versed in the features of the language. He never used stinginess in talking about knowledge and action. He spent forty years in such a state that he had a book on his chest. Hassan Basri (may Allah have mercy on him) was the famous jurisprudence of his time. In the words of one scholar, Hasan stands as the "great patriarch" of early Sufism and was frequently designated as one the well-respected of the early Islamic community.

\section{References}

Akhtar, A. B. (2004). Allah ki Aashoqoun ki Halat (Vol. 1). Karachi, Pakistan/Sindh, Pakistan: Maktaba Arsalan.

Ahmad, I. (2013). The wise saying of Hassan Basri (1st ed.). (I. AHMAD, Ed.) Mumbai, Mumbai, India.

Al-'Asqalani, I. I. (2004). Preparing For The Day Of Judgement (1ST ed., Vol. 1). London, London, UK.

Al-Hasan A. B. (2017, May 15). Retrieved 2 2, 2019, from Islam Web: http://www.islamweb.net/ en/article/136052/al-hasan-al-basri

Al-Hanbalee ( 1401H). The Evil Of Craving For Wealth And Status (1st ed., Vol. 1). (B. `. al-Badr, Ed., \& A. T. Burbank, Trans.) Rabee'uth-Thanee, Kuwait, Kuwait: Al-Hidaayah.

Al-Ajurri, I. A.-H. (360H). THE CHARACTER OF THE PEOPLE OF THE QURAN (1ST ed., Vol. 1). (U. H. Hasan, Trans.) London, UK, UK: Al-Qur'an Society

Al Madani. (2000). In the school of Ali Shah Al-Madani: MotamerolMosanefeen, Pakistan

Al-Nimri, (2010). Jami Bayan Akhz al-Ilm Wa Fadlih (1st ed., Vol. 2). samarqand, uzbakistan: Darul Imam Bukhari.

Naadvi, S. A. (2006). Saviour of Islamic Spirit (1st ed., Vol. 1). (M. Ahmad, Trans.) a gang, Dehli, India: ICON PUBLICATIONS PVT. LTD Naadvi, S. A. (2008). Saviour of Islamic Spirit (1st ed., Vol. 1). (M. Ahmad, Trans.) a gang, Dehli, India: ICON PUBLICATIONS PVT. LTD

Abn-aljawzi, A.-H. A. (2012). Awakening from the sleep of heedlessness (1st ed., Vol. 1). (A. i. Khalid, Trans.) London, UK, UK: Darees Sunnah.

Adrees, R.. (2004). The bright lamp of the Ummah, VoIl. PP 192, Maktab-e-Taiba near Safid Masjid, Deoband, Saharanpur.

Aftikhar, A. (2019). The wise saying of Hasan al. Basri, Amazon Digital Services LLC - KDP Print US, 2019

John Renard,( 2008). Friend of God: Islamic Images of Piety, Commitment, and Servanthood (Berkeley: University of California Press.

Mourad, Suleiman A..(2003). "al-Hasan al-Bașrī", in: Encyclopaedia of Islam, THREE, Edited by: Kate Fleet, Gudrun Krämer, Denis Matringe, John Nawas, Everett Rowson

Saifullah, Q. (2003)Virtue of knowledge and wisdom, vol 2nd, Sharifa Book Depot Gangoh District Saharanpur UP India

Shah, (2017). Imam Hassan Basri Ahwal Wa Aasar (1st ed., Vol. 1). (M. J. Akhonzada, Trans.) Peshawar, kpk, Pakistan: Majlees tahqiqat Islami Nowshehra. 